\title{
Techniques to Estimate Colostrum Quality and the Effects of Cow Age and Pre-Partum Supplement Intake Levels on Colostrum Quality and Serum IgG Levels
}

\author{
Julia M. Dafoe \\ Northern Agricultural Research Center, Montana State University \\ 3710 Assinniboine Road, Havre, MT 59501, United States \\ Tel: 1-406-265-6115Ｅ-mail: jdafoe@montana.edu
}

Samuel A. Wyffels (Corresponding author)

Northern Agricultural Research Center, Montana State University

3710 Assinniboine Road, Havre, MT 59501, United States

Tel: 1-541-805-5792_E-mail: samwyffels@montana.edu

Cory T. Parsons

Northern Agricultural Research Center, Montana State University 3710 Assinniboine Road, Havre, MT 59501, United States

Tel: 1-541-403-0042Ｅ-mail: cory.parsons@student.montana.edu

Timothy DelCurto

Dept. of Animal and Range Sciences, Montana State University

PO Box 172900, Bozeman, MT 59717, United States

Tel: 1- 406-994-3708 E-mail: timothy.delcurto@montana.edu

Darrin L. Boss

Northern Agricultural Research Center, Montana State University 3710 Assinniboine Road, Havre, MT 59501, United States 
Tel: 1-406-265-6115_E-mail: dboss@montana.edu

Received: Aug. 3, 2020

doi:10.5296/jas.v8i4.17463
Accepted: Aug. 26, 2020

Published: Sep. 15, 2020

URL: https://doi.org/10.5296/jas.v8i4.17463

\begin{abstract}
This study evaluated cow age and supplement intake level during gestation on the quality of colostrum at calving, cow serum immunoglobulin $\mathrm{G}(\mathrm{IgG})$ levels at parturition, and serum IgG levels of the calf 3-days post-partum using two refractometer methods. Forty-five multiparous Angus cows were selected from a contemporary group of 300 cows that were winter grazing northern mixed grass prairie rangelands with free choice protein supplement. Specifically, 15 first service bred cows were selected for each of the following winter grazing supplement intake treatment groups: 1) low supplement intake (>-0.75 SD); 2) average supplement intake ( $\pm 0.50 \mathrm{SD}) ; 3$ ) high supplement intake (> +0.75 SD). Supplement intakes were measured using a SmartFeed Pro self-feeder system with 8 feeding units. Measurements were obtained from day 164 to 215 of gestation. Cows were further divided by age comparing young $(4,5$, and $6 \mathrm{yr})$ to old $(7,8$ and $9 \mathrm{yr})$. The results of this study suggest that cow age did not interact with supplement intake for colostrum or blood serum measurements $(P \geq 0.29)$. In addition, cow age and supplement intake did not influence colostrum Brix $\%$, calf serum total protein, or cow serum total protein taken at birth $(P \geq 0.14)$. The optical refractometer was found to be a good alternative to the more expensive digital refractometer $(P<0.01 ; R$ $=.96$ ). In summary, cow age and supplement intake levels of mature cows during the mid to late stages of gestation did not influence colostrum quality at birth.
\end{abstract}

Keywords: beef cattle, protein supplements, supplement intake, colostrum quality, cow age

\title{
1. Introduction
}

In cattle, colostrum is the primary source of nutrients and immunity for the newborn calf, hence ingestion of sufficient quality and quantity of colostrum following birth is essential for the future health and performance of the newly born calf (Rauprich et al., 2000). At birth, calves have limited immune function because there is no transfer of immunoglobulin across the placenta from the dam to the fetus (Larson et al., 1980). This means that newborn calves must acquire passive immunity through the consumption of colostrum immunoglobulin $G$ (IgG). Colostrum quality, as measured by its IgG content, can vary among cattle within a herd and across breeds (Gulliksen et al., 2008). The ingestion and absorption of adequate IgG is called passive transfer immunity and allows the newborn calf to build natural immunity for improved lifetime health and production (Calloway et al., 2002), and failure of passive transfer is a condition that predisposes the newborn calf to the development of diseases (Weaver et al., 2000). Numerous tools are available to measure on farm colostrum quality; these include a colostrometer or Brix refractometer. Total serum protein, a blood serum test to assess the absorption of adequate quality and quantity of colostrum, can also be assessed using both the digital and optical refractometer in newborn calves (Penn State University, 
2016). A colostrum \% Brix value of $>22$ is considered to contain adequate IgG to support effective passive transfer insuring the future health and production of the calf (Elsohaby et al., 2015).

Factors that are often cited as impacting passive transfer of immunity in calves are timing of colostrum ingestion, method of administration and volume of colostrum, IgG concentration, age of the dam, and plane of nutrition including mineral and supplementation intake of the dam (Weaver et al. 2000). In order to meet the nutritional needs and maintain a desired level of productivity of beef cattle during winter months, supplemental protein is often provided to increase intake of dormant forages and, as a result, performance (Lusby et al., 1967; Bowman et al., 1995; Bodine et al., 2001). Supplementation strategies assume that all animals consume a target quantity of supplement and deviation from the target intake can have deleterious effects on animal performance, reflected as decreased profit for the producer (Bowman and Sowell, 1997). Cow age has been shown to be an influential factor effecting individual supplement intake and foraging behavior (Adams et al., 1986; Kincheloe et al., 2004; Walburger et al., 2009). Therefore, understanding how late gestational nutrition of beef cattle grazing extensive rangeland environments influences subsequent colostrum quality at birth is important for calf health, survival and overall ranch production.

The objectives of this study were to 1) determine the impacts of differential protein supplement intake during gestation with winter grazing beef cattle on post-calving colostrum quality and total serum protein of both cows and calves; and 2) evaluate the effectiveness of a digital versus optical Brix refractometer at measuring the colostrum quality of beef cattle. Our hypotheses were: 1) differential protein supplement intake during mid to late gestation would influence colostrum quality or total serum protein in multiparous beef cattle, and 2) optical BRIX refractometers are an economical alternative to Digital BRIX methods to assess colostrum quality.

\section{Method}

The use of animals in this study was approved by the Agricultural Animal Care and Use Committee of Montana State University AACUC \#2018-AA12.

Research was conducted at Montana State University's Northern Agricultural Research Center, Havre, MT. Multiparous artificial insemination bred (June 2, 2018) Angus cows $(\mathrm{n}=45)$ four to nine years of age were divided into two age classes, young (4-6-yr-olds; $\mathrm{n}=$ 22) and old $(7-9$-yr-olds; $n=23)$, and winter grazed dormant forage from mid-November to early-January 2018 - 2019. All cattle were provided a free-choice access to a $28.7 \%$ crude protein self-fed pressed block supplement with a target daily intake range of $0.45-0.91 \mathrm{~kg}$. $\operatorname{cow}^{-1} \cdot \mathrm{d}^{-1}$. The supplement included salt (23\%), bitterness, and hardness as mechanisms to limit supplement intake (Table 1). Each individual animal was equipped with an electronic ID tag (Allflex USA, Inc., Dallas-Ft. Worth, TX) attached to the interior of the left ear for the measurement of daily individual supplement intake $\left(\mathrm{kg} \cdot \operatorname{cow}^{-1} \cdot \mathrm{d}^{-1}\right)$ using a SmartFeed Pro self-feeder system (C-Lock Inc., Rapid City, SD) with a total of 8 feeding stations. Cows had ad libitum access to the supplement starting in their second trimester (129 day of pregnancy) through parturition; however, intakes were only measured from day $164-215$ of pregnancy. 


\section{Macrothink}

Table 1. Bovibox HM supplement composition for cattle winter grazing rangeland in 2018 2019 at the Thackeray Ranch, Havre MT (as-fed basis)

\begin{tabular}{ll}
\hline Crude Protein & $28.7 \% \mathrm{~min}$ \\
Crude Fat & $1.45 \% \mathrm{~min}$ \\
Crude Fiber & $5.0 \% \mathrm{max}$ \\
Calcium & $1.3 \% \mathrm{~min}$ \\
& $1.8 \% \mathrm{max}$ \\
Phosphorus & $0.7 \% \mathrm{~min}$ \\
Salt & $23 \% \mathrm{~min}$ \\
& $26 \% \mathrm{max}$ \\
Potassium & $1.5 \% \mathrm{~min}$ \\
Magnesium & $2.5 \% \mathrm{~min}$ \\
Manganese & $856 \mathrm{ppm} \min$ \\
Zinc & $1,074 \mathrm{ppm}$ min \\
Copper & $213 \mathrm{ppm} \mathrm{min}$ \\
Copper (from Chelate) & $108 \mathrm{ppm} \mathrm{min}$ \\
Cobalt & $15 \mathrm{ppm} \mathrm{min}$ \\
Iodine & $26 \mathrm{ppm} \mathrm{min}$ \\
Selenium & $3.3 \mathrm{ppm} \min$ \\
& $3.6 \mathrm{ppm} \mathrm{max}$ \\
Selenium Yeast & --------------- \\
Vitamin A & $26,455 \mathrm{IU} / \mathrm{kg}$ \\
Vitamin D & $8,818 \mathrm{IU} / \mathrm{kg}$ \\
Vitamin E & $55 \mathrm{IU} / \mathrm{kg}$ \\
NPN & $9.7 \%$ \\
\hline
\end{tabular}

${ }^{1}$ Non-protein nitrogen

Cows were categorized as either low ( $>-0.75$ SD from mean), average ( \pm 0.50 SD from mean) or high ( $>+0.75$ SD from the mean) supplement consumers based on calculated supplement intake during days $164-215$ of pregnancy. Only cows that conceived first service artificially inseminated pregnancy were used to ensure data collection occurred within similar time during the calving season. Twenty cows of each intake group were randomly identified and observed for signs of calving and the first 15 cows in each group to calve were selected for the study. Average daily supplement intakes were $0.12,0.32$ and $0.67 \mathrm{~kg} \mathrm{cow}^{-1} \mathrm{~d}^{-1}$ for the low, average and high supplement intake groups, respectively. Both the low and average intake treatment were below the target label daily-recommended intake range of $0.45-0.91 \mathrm{~kg}$. $\operatorname{cow}^{-1} \cdot \mathrm{d}^{-1}$.

All cows in this study were housed together in a small pasture and observed hourly for signs of parturition. If no assistance was needed the pair was left in the pasture until data was collected from the dam. Once parturition occurred, calves were observed to ensure they had nursed within 2-hours of birth. Cows that had calved within the last 12-hours were brought into the barn at 0700- or 1900-hours. A 50-ml colostrum sample was collected uniformly from all 4 teats and composited. Colostrum quality was measured using an optical Brix scale 
(Bellingham + Stanley, Lawrenceville, GA 30043) and a digital Brix scale (Misco Palm Abbe, Solon, OH) using methods outlined by Quigley and coworkers (2013). Due to the extreme cold weather, calves in each treatment group $(n=3$ for High, $n=2$ for average, and $n=4$ for low) were brought into the barn and treated for hypothermia (rectal temperature of less than $36{ }^{\circ} \mathrm{C}$ ). Hypothermic calves were treated with $50 \%$ Dextrose solution, placed in a warm environment, and fed colostrum from their dam to ensure calves received adequate colostrum within 2-hours of birth.

At time of milk collection, a 10-ml blood sample was collected from the dam via venipuncture utilizing vacutainer tube without anticoagulant. Serum was separated by centrifugation within an hour of collection; the sample was spun at 2100 RPM for 15-minutes. The serum sample was tested for total protein $\left(\mathrm{g} \cdot \mathrm{dL}^{-1}\right)$ using a digital refractometer. Calf blood samples (10-ml) were collected three days post-partum via venipuncture utilizing vacutainer tube without anticoagulant. Serum was separated by centrifugation within an hour of collection; the sample was spun at 2100 RPM for 15 -minutes. The serum sample was tested for total protein $\left(\mathrm{g} \cdot \mathrm{dL}^{-1}\right)$ using digital refractometer.

Data were analyzed using generalized linear models in an ANOVA evaluating the effects of supplement intake levels and cow age on \% Brix of colostrum, and total protein content of cow and calf serum. Linear regression was used to evaluate the relationship of colostrum level to cow serum and calf serum 3-day post-partum, \% Brix of colostrum to the hour post-partum that colostrum was collected, and the relationship of the two refractometer methods. Least square means were separated using the Tukey method when $P<0.05$. Tendencies were considered when $P<0.10$. Cow was considered the experimental unit and all statistical analyses were performed in R (R Core Team 2017).

\section{Results}

Beef cattle age and supplement intake level did not interact with colostrum \% Brix, nor cow and calf serum total protein $(P \geq 0.29)$. As a result, data are presented as main effects relative to cow age (Table 2) and supplement intake level (Table 3). Cow age classification had no effect on colostrum \% Brix $(P=0.94)$, cow serum total protein $(P=0.62)$, and calf serum total protein $(P=0.14$; Table 2$)$. There were also no differences observed between supplement intake levels and estimated colostrum quality as measured using a digital refractometer $(P=0.35$; Table 3$)$. In addition, supplement intake had no effect on total protein of cow serum taken within 12-hours of parturition nor total protein of calf serum taken at day 3 post-partum $(P \geq 0.14)$. 


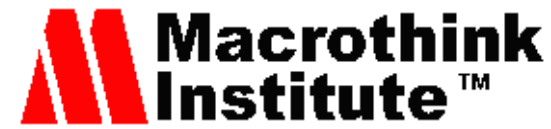

Table 2. Effect of cow age on body weight, body condition, colostrum quality, cow serum and calf serum

\begin{tabular}{|c|c|c|c|c|}
\hline & \multicolumn{2}{|c|}{ Cow age $^{1}$} & \multirow[b]{2}{*}{$\mathrm{SE}$} & \multirow[b]{2}{*}{$P$-Value } \\
\hline & Young & Old & & \\
\hline \multicolumn{5}{|l|}{ Cow weight, $\mathrm{kg}$} \\
\hline Day 129 gestation & 568.3 & 623.6 & 9.97 & \\
\hline Day 215 gestation & 604.0 & 649.3 & 9.02 & \\
\hline \multicolumn{5}{|l|}{ Cow Body Condition Score ${ }^{2}$} \\
\hline Day 129 gestation & 5.42 & 5.73 & 0.09 & \\
\hline Day 215 gestation & 5.53 & 5.58 & 0.08 & \\
\hline Colostrum, \% Brix ${ }^{3}$ & 25.1 & 26.3 & 0.80 & 0.94 \\
\hline Cow Serum Total Protein ${ }^{3}, \mathrm{~g} \cdot \mathrm{dL}^{-1}$ & 6.67 & 6.94 & 0.11 & 0.62 \\
\hline Calf Serum Total Protein ${ }^{4}, \mathrm{~g} \cdot \mathrm{dL}^{-1}$ & 6.15 & 6.80 & 0.19 & 0.14 \\
\hline \multicolumn{5}{|c|}{${ }^{1}$ Young cows $=4,5$, and $6 \mathrm{yr}$; Old cows $=7,8$ and $9 \mathrm{yr}}$. \\
\hline \multicolumn{5}{|l|}{${ }^{2} 1-9$ scale } \\
\hline \multicolumn{5}{|c|}{$\begin{array}{l}{ }^{3} \text { cow serum and colostrum were collected within } 12 \text {-hours of parturition } \\
\text { average collection time was } 5.25 \text {-hours after parturition }\end{array}$} \\
\hline
\end{tabular}

Table 3. Influence of protein supplement intake during gestation on beef cattle weight and body condition as well as post-partum colostrum quality, cow blood serum, and calf blood serum

\begin{tabular}{|c|c|c|c|c|c|}
\hline & \multicolumn{3}{|c|}{ Protein supplement intake ${ }^{1}$} & \multirow[b]{2}{*}{ SE } & \multirow[b]{2}{*}{$P$ - value } \\
\hline & Low & Average & High & & \\
\hline \multicolumn{6}{|l|}{ Cow weight, kg } \\
\hline Day 129 gestation & 607.4 & 594.1 & 588.3 & 13.95 & \\
\hline Day 215 gestation & 630.3 & 622.9 & 627.8 & 12.40 & \\
\hline \multicolumn{6}{|l|}{ Cow Body Condition Score ${ }^{2}$} \\
\hline Day 129 gestation & 5.67 & 5.65 & 5.42 & 0.09 & \\
\hline Day 215 gestation & 5.67 & 5.58 & 5.27 & 0.09 & \\
\hline Colostrum, \% Brix ${ }^{3}$ & 26.2 & 24.7 & 26.7 & 0.99 & 0.34 \\
\hline Cow Serum Total Protein ${ }^{3}, \mathrm{~g} \cdot \mathrm{dL}^{-1}$ & 6.92 & 6.51 & 6.98 & 0.14 & 0.22 \\
\hline Calf Serum Total Protein ${ }^{4}, \mathrm{~g} \cdot \mathrm{dL}^{-1}$ & 6.16 & 6.59 & 6.67 & 0.23 & 0.30 \\
\hline \multicolumn{6}{|c|}{$\begin{array}{l}{ }^{1} \text { Cows were categorized as either low }(>-0.75 \text { SD), or average }( \pm 0.50 \text { SD) or high } \\
(>+0.75 \text { SD) based on mean daily supplement intake. } \\
21-9 \text { scale }\end{array}$} \\
\hline $\begin{array}{l}3 \text { cow serum and colostrum were col } \\
\text { collection time was 5.25-hours aft } \\
4 \text { calf serum was collected } 3 \text {-davs } n\end{array}$ & ected w & $\begin{array}{l}\text { hin } 12-\text { hou } \\
\text { ion }\end{array}$ & of partı & rition a & erage \\
\hline
\end{tabular}

No relationships were observed between colostrum $\%$ Brix and total protein of cow serum at parturition $(P=0.73 ; R=-0.05$; Figure 1$)$. However, total protein of calf serum tended to be related to colostrum $\%$ Brix levels although the relationship was minimal $(P=0.07 ; R=0.27$; Figure 2). Colostrum $\%$ Brix decreased as hours post-partum that colostrum was collected increased ( $R=-0.31, P=0.04$; Figure 3$)$. The optical refractometer was found to be a good alternative to the more expensive digital refractometer. When regressing values of the two 
techniques, they were observed to be similar and both gave values that were closely related $(P<0.01 ; R=.96 ;$ Figure 4$)$.

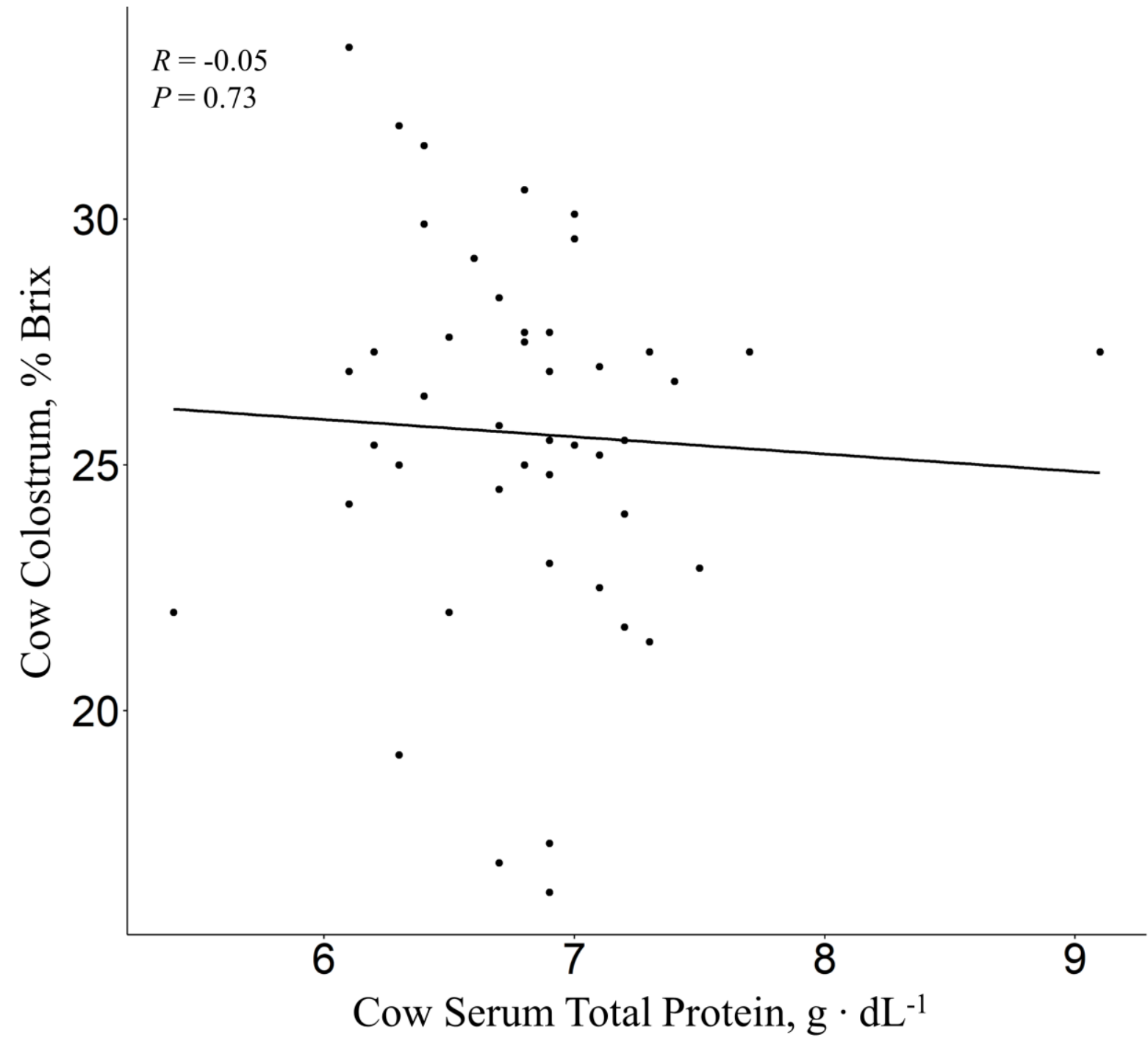

Figure 1. Relationship of cow colostrum (\% Brix) and cow blood serum total protein $\left(\mathrm{g} \cdot \mathrm{dL}^{-1}\right)$ obtained within 12-hours post-partum multiparous spring calving commercial Angus beef cattle 


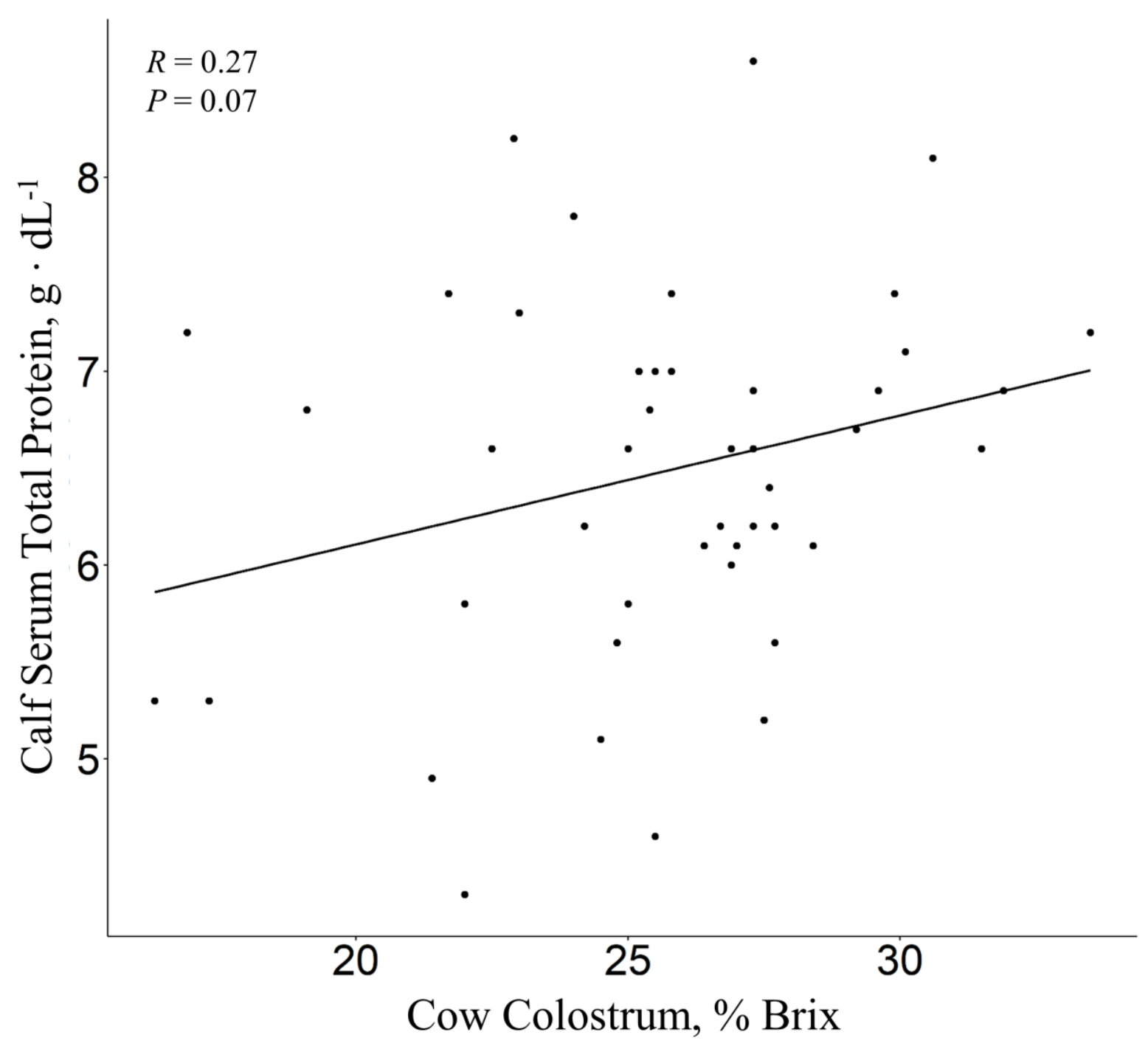

Figure 2. Relationship of cow colostrum (\% Brix) obtained within 12-hours post-partum to calf blood serum total protein $\left(\mathrm{g} \cdot \mathrm{dL}^{-1}\right)$ taken 3-days post-partum with multiparous spring calving commercial Angus beef cattle 


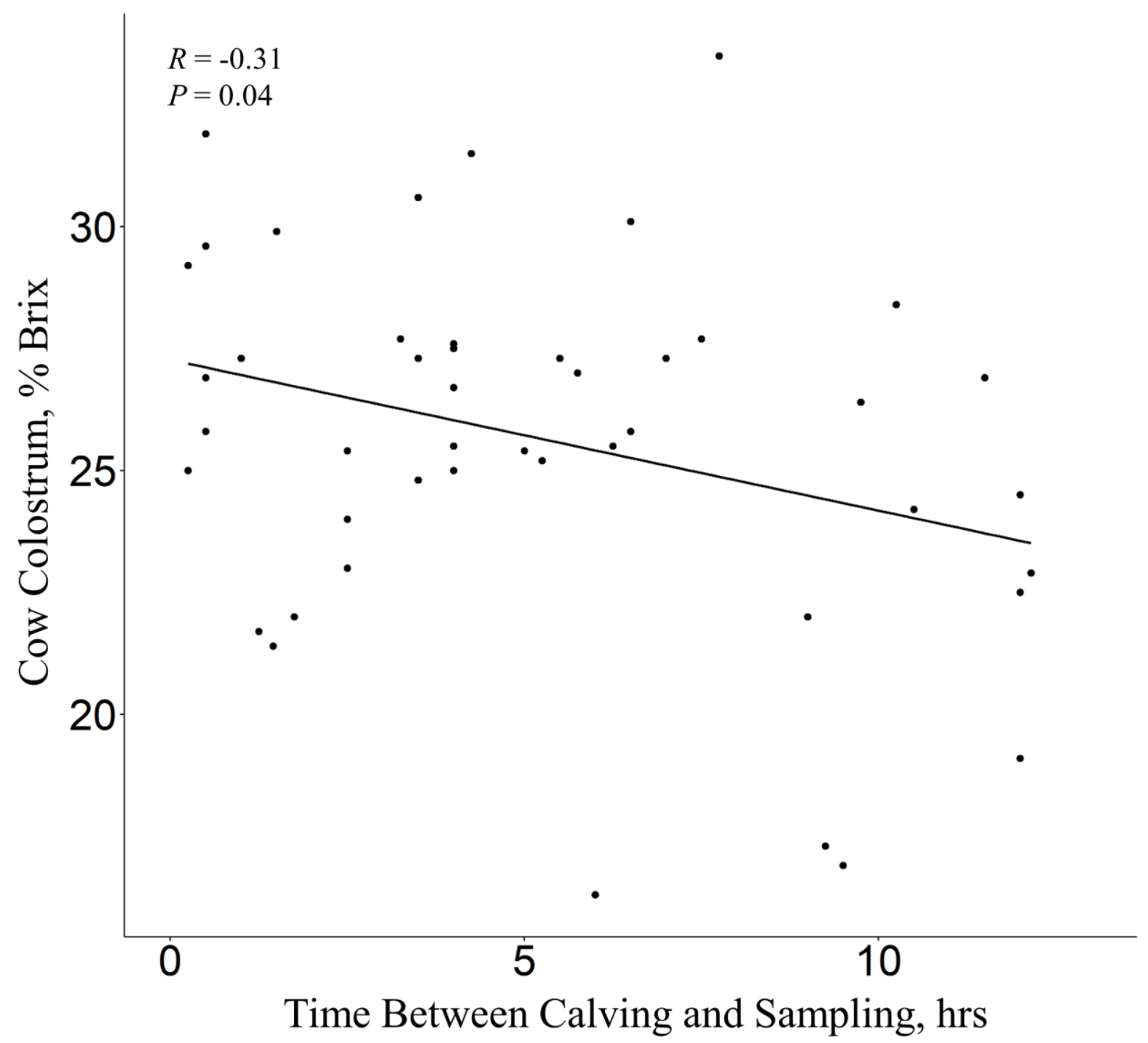

Figure 3. Correlation between Colostrum Brix score and hours post-partum samples were taken with multiparous, spring calving Angus cows 


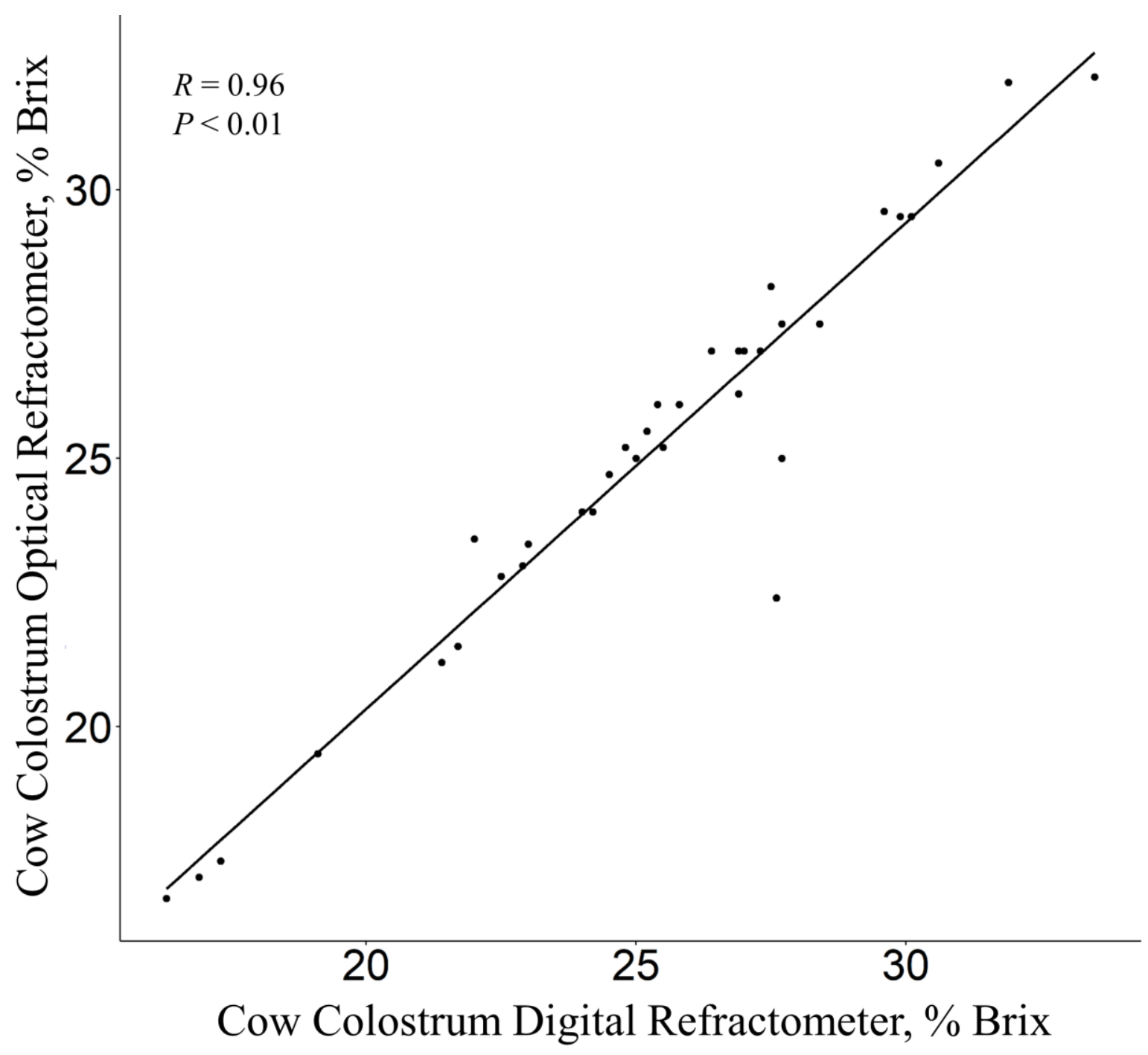

Figure 4. Comparison of digital versus optical refractometers to assess colostrum quality (\% Brix) in beef cattle with samples taken within 12-hours post-partum

\section{Discussion}

A colostrum \% Brix value of $>22 \%$ is considered to contain adequate IgG to support effective passive transfer and future health and production, demonstrating that $23 \%$ Brix should be used as a minimum threshold for adequate quality colostrum (Elsohaby, et al 2015). Therefore, the values observed in this study suggested that most cows met or exceeded the IgG levels needed to ensure proper passive transfer for calf health, provided that the calves consumed the colostrum in a timely manner post-partum (Buczinski and Vandeweerd 2016). We did not observe any influence of gestational supplement intake level or cow age on colostrum quality estimated with digital refractometers. This may be due to the relatively good body condition of the cows during the winter grazing part of gestation, demonstrated by body condition scores greater than 5 at the end of the study period (Table $2 \& 3$ ) and at calving. In addition, from day 215 of gestation to calving, cows were fed a moderate quality diet combined with the protein supplement, which likely met or exceeded $3^{\text {rd }}$ trimester beef cow nutritional needs. Simply put, the relative condition of the cows at birth likely limited 
our ability to observe differences in colostrum quality due to differences in supplement intake.

In our study, colostrum \% Brix decreased as hours post-partum increased in respect to sample collection. These findings are similar to that of Foley and Otterby (1978) who reported that colostrum IgG decreased slightly in the first 24-hours post-partum and sharply afterwards in dairy cows. The decline in Brix values as a function of hour post-partum were small and highly variable in our study, which likely did not contribute to the lack of statistical inference in respect to cow age and supplement intake.

Cow age and supplement intake levels of mature cows during the mid- to late-stages of gestation did not influence colostrum quality at birth. The lack of colostrum quality differences was likely due to the moderate to good condition of the cows and adequate nutrition 90-days prior to parturition. Additionally, the optical refractometers produced very similar results to the more expensive digital refractometer making it an economical alternative for measuring colostrum quality.

Future research evaluating late gestational nutrition of beef cattle on subsequent colostrum quality ( $\mathrm{IgG}$ ) is important for optimizing beef cattle production in extensive rangeland environments. Although the results of our study showed little effect of supplement intake and cow age on colostrum quality, cattle were in good condition and were provided an adequate diet the last 60-days of gestation. Beef cattle management that results in body condition loss and/or nutrient deprivation during the last trimester may result in a decrease in colostrum quality. Therefore, future research is needed where nutritional stress and subsequent colostrum quality is evaluated for the last 60-days of gestation.

\section{References}

Adams, D., Nelsen, T., Reynolds, W., \& Knapp, B. (1986). Winter grazing activity and forage intake of range cows in the Northern Great Plains. Journal of Animal Science, 62(5), 1240-1246. https://doi.org/10.2527/jas1986.6251240x

Bodine, T., Purvis, H., \& Lalman, D. (2001). Effects of supplement type on animal performance, forage intake, digestion, and ruminal measurements of growing beef cattle. Journal of Animal Science, 79(4), 1041-1051. https://doi.org/10.2527/2001.7941041x

Bowman, J., \& Sowell, B. (1997). Delivery method and supplement consumption by grazing ruminants: a review. Journal of Animal Science, 75(2), 543-550. https://doi.org/10.2527/1997.752543x

Bowman, J., Sowell, B., \& Paterson, J. (1995). Liquid supplementation for ruminants fed low-quality forage diets: a review. Animal Feed Science and Technology, 55(1), 105-138. https://doi.org/10.1016/0377-8401(95)98203-9

Buczinski, S., \& Vandeweerd, J. M. (2016). Diagnostic accuracy of refractometry for assessing bovine colostrum quality: A systematic review and meta-analysis. Journal of Dairy Science, 99(9), 7381-7394. https://doi.org/10.3168/jds.2016-10955 
Calloway, C. D., Tyler, J. W., Tessman, R. K., Hostetler, D., \& Holle, J. (2002). Comparison of refractometers and test endpoints in the measurement of serum protein concentration to assess passive transfer status in calves. Journal of the American Veterinary Medical Association, 221(11), 1605-1608. https://doi.org/10.2460/javma.202.221.1605

Elsohaby, I., McClure, J. T., \& Keefe, G. P. (2015). Evaluation of digital and optical refractometers for assessing failure of transfer of passive immunity in dairy calves. Journal of Veterinary Internal Medicine, 29, 721-726. https://doi.org/10.1111/jvim.12560

Foley, J. A., \& Otterby, D. E. (1978). Availability, storage, treatment, composition, and feeding value of surplus colostrum: A review. Journal of Dairy Science, 61, 1033-1060. https://doi.org/10.3168/jds.S0022-0302(78)83686-8

Gulliksen, S. M., Lie, K. I., Solverod, L., \& Osteras, O. (2008). Risk factors associated with colostrum quality in Norwegian dairy cows. Journal of Dairy Science, 91, 704-712. https://doi.org/10.3168/jds.2007-0450

Kincheloe, J., Bowman, J., Sowell, B., Ansotegui, R., Surber, L., \& Robinson, B. (2004). Supplement intake variation in grazing beef cows. Proceedings- Western Section American Society of Animal Science, 331-334.

Larson, B. L., Heary, H. L., \& Devery, J. E. (1980). Immunoglobulin production and transport by the mammary gland. Journal of Dairy Science, 63, 665-671. https://doi.org/10.3168/jds.S0022-0302(80)82988-2

Lusby, K., Stephens, D. , Knori, L., \& Totusek, R. (1967). Forage intake of range cows as affected by breed and level of winter supplement. Oklahoma Agricultural Experiment Station Research Report, MP-96, 27-32.

Penn State University Extension.

(2019)

https://extension.psu.edu/colostrum-management-tools-hydrometers-and-refractometers accessed 3/1/2020. accessed: 1/29/2019

Quigley, L., O’Sullivan, O., Stanton, C., Beresford, T. P., Ross, R. P., Fitzgerald, G. F., \& Cotter, P. D. (2013). The complex microbiota of raw milk. FEMS Microbiology Reviews, 37, 664-698. https://doi.org/10.1111/1574-6976.12030

R Core Team. (2017). R: A language and environment for statistical computing. R Foundation for Statistical Computing: Vienna, Austria. Available at: http://www.R-project.org/. accessed $11 / 15 / 2017$

Rauprich, A. B. E., Hammon, H. M., \& Blum, J. W. (2000). Influence of feeding different amounts of first colostrum on metabolic, endocrine, and health status and on growth performance in neonatal calves. Journal Animal Science, 78, 896-908. https://doi.org/10.2527/200.784896x

Walburger, K. J., Wells, M., Vavra, M., DelCurto, T., Johnson, B., \& Coe, P. (2009). Influence of cow age on grazing distribution in a mixed-conifer forest. Rangeland Ecology \& Management, 62(3), 290-296. https://doi.org/10.2111/08-163R1.1 


\section{Macrothink}

Journal of Agricultural Studies

ISSN 2166-0379 2020, Vol. 8, No. 4

Weaver, D. M., Tyler, J. W., VanMetre, D. C., Hostetler, D. E., \& Barrington, G. M. (2000). Passive transfer of colostral immunoglobulins in calves. Journal of Veterinary Internal Medicine, 14, 569-777. https://doi.org/10.1111/j.1939-1676.2000.tb02278.x

\section{Copyright Disclaimer}

Copyright for this article is retained by the author(s), with first publication rights granted to the journal.

This is an open-access article distributed under the terms and conditions of the Creative Commons Attribution license (http://creativecommons.org/licenses/by/4.0/). 